\title{
Ecosystem of Medicinal Plants Species and Potential of Growing on the Dumps of Kedrovsky Surface Mine (Kemerovo Region)
}

\author{
Irina Egorova ${ }^{1, *}$, Olga Neverova, ${ }^{2}$ and Tatyana Grigorieva ${ }^{3}$ \\ ${ }^{1}$ The Federal Research Center of Coal and Coal Chemistry of SB RAS (Institute of Human Ecology \\ of the SB RAS), Leningradskiy avenue, 10, Kemerovo, 650065, Russia \\ ${ }^{2}$ Kemerovo State University (KemSU), 73, Sovietskiy pr., Kemerovo, 650000, Russia \\ ${ }^{3}$ T.F. Gorbachev Kuzbass State Technical University, 650000, 28 Vesennyaya St., Kemerovo, Russia
}

\begin{abstract}
Annotation. The medicinal flora of phytocenosis "Yuzhny" waste dump Kedrovsky coal mine pit in Kemerovo region was studied. It has been established that 51 species of medicinal plants belonging to 46 genus and 27 families grow on the waste dump. They are permitted for use in official medicine and included in the Medicines State Register in the territory of the Russian Federation. The most of medicinal plants species are represented by forest (39.22\%), ruderal (27.45\%) and meadow (23.53\%) vegetation, which in general is $90.2 \%$ of the identified medicinal plants number. The share of semi-aquatic and steppe vegetation accounts for $7.84 \%$ and $1.96 \%$, respectively. It has been established that perennial herbaceous plants $(25$ species) predominate in the life forms composition; shrubs and trees account for 7 and 9 species, respectively. Researches were established a group of medicinal plants with resource potential and interest in raw materials procurement. This group include 13 herbaceous plants (Achillea millefolium L., Viola arvensis Murr., Polygonum aviculare L., Melilotus officinalis (L.) Pall., Fragaria vesca L., Verbascum thapsus L., Urtica dioica L., Filipendula ulmaria (L.) Maxim., Tussilago farfara L., Taraxacum officinale Web., Tanacetum vulgare L., Plantago major L., Artemisia absinthium L.), 5 shurbs (Crataegus sanguínea Pall., Hippophaë rhamnoides L., Rosa accicularis Lindl., Rosa majalis Herm., Viburnum opulus L.) and 5 trees ( Betula pendula Roth., Betula pubesccens Ehrh., Padus avium Mill., Sorbus sibirica Hedl., Pinus sylbestris L.).
\end{abstract}

\section{Introduction}

Kemerovo region coal-mining enterprises work entails a large loss of land resources. The natural habitats of many valuable wild plants, including medicinal plants and the area of their natural phytocenoses are reduced. The restoring processes of disturbed land are slow. Predominantly technogenic lands incur to natural overgrowing, due to the drift of seeds from the surrounding territories. Also a reclamation biological stage is carried out by planting trees and grass mixtures. The most commonly used tree and shrub species are: Larix sibirica

\footnotetext{
* Corresponding author: $\underline{\text { nir_kem@,mail.ru }}$
} 
Ledeb., Pinus sylvestris L., Picea obovata Ledeb., Pinus sibirica Du Tour., Abies sibirica Ledeb., Betula pendula Roth., Populus balsamifera L., Hippophae rhamnoides L., Crataegus sanguínea Pall., Caragana arborescens Lam., Sambucus sibirica Nakai., Sorbus sibirica Hedl., Padus avium Mill. and etc. From herbaceous plants in the planting mixture is injected: Medicago L., Trifolium L., Galega orientalis Lam., Bromopsis inermis (Leyss.) Holub. Agropyron Intermidium (Host.) Beauv., Festuca pratensis Huds., Melilotus albus Desr. and the medicinal plant Melilótus officinális L. etc [1-3]. Many of these species not only have the pronounced highly effective phytomeliorant properties that performs soil-protective and environment-forming functions, but also have certain pharmacological properties (Hippophae rhamnoides L., Crataus sanguinea Pall., Melilótus officinális L. etc.) [4,5]. In addition, a large number of introduced species (Tussilago farfara L., Fragaria vesca L., Arctium lappa L., Plantago major L., etc.) are found on the dumps, many of which are medicinal [4].

Phyto and zoocenoses are formed on the dumps over time, including species which typical for the area and the soil formation process is actively taking place. There is an improvement in the environmental situation. The earlier studies of environmental and hygienic assessment of the medicinal plants raw materials growing on the "Yuzhny" dump Kedrovsky coal mine are showed that it meets the requirements of regulatory documents and does not pose a danger to human life and health [6-12].

In this regard, the research of phytocenoses medicinal flora formed on the dumps of coal mines is seem to be perspective, cause it will increase the medicinal plant raw material base.

The purpose of this work is to study the medicinal flora species composition and resource potential of phytocenoses Kedrovsky coal mine dumps.

\section{Materials and Methods}

Studies were conducted on the "Yuzhny" waste dump of OJSC open-pit mine "Kedrovsky". Waste age is $35-40$ years. Waste pile are represented by sandstone $(60 \%)$, siltstones $(20 \%)$, mudstones $(15 \%)$, loams and clays $(5 \%)$. According to the soils classification by N. A. Kachinsky, the waste young soils are medium loam [8]. Soils are characterized by alkaline reaction ( $\mathrm{pH}$ of the aqueous extract is $7.1-7.7)$, medium supply of humus $(3.5 \%)$, low availability of phosphorus mobile forms $(10 \ldots 50 \mathrm{mg} / \mathrm{kg})$ and nitrogen $(3.6 \ldots 6.0 \mathrm{mg} / \mathrm{kg})$, high availability of exchangeable potassium ( $100 \ldots 140 \mathrm{mg} / \mathrm{kg}$ ), lack of productive moisture (19-22 $\mathrm{mm}$ in $0 \ldots 20 \mathrm{~cm}$ layer). Phytocenoses on the dumps are formed due to natural self-overgrowth and with biological remediation works complex (planting Pinus sylvestris L. and Onobrychis arenaria (Kit.) DC.). Studies have been conducted in various dump microreliefs. Projective cover up to $50 \%$, on rocky areas - below $10 \%$. There is no sodding. In the herbage prevail Onobrychis arenaria (Kit.) DC., Taraxacum officinale Wigg., Melilotus officinalis (L.) Pall., Artemisia sericea Web. ex Stechm., Picris hieracioides L. [13].

The research material was the medicinal plants flora of the Kedrovsky coal mine dump in the summer period of 2011-2014.

The main research methods are observations in nature and the herbarium material collection, herbarium collections analysis (FIC UUK SB RAS, KemSU) and literary sources analysis. The obtained data were processed using standard floristic analysis. Latin species names are given by Cherepanov (1995) [14-15]. 


\section{Results and Discussion}

In the course of research on dumps, 51 medicinal plants species belonging to 46 genus and 27 families allowed for use in official medicine in the territory of the Russian Federation were identified (Table 1). The most numerous is the Rosaceae family (10 species), then follows - Asteraceae (8 species), then - Apiaceae and Pinaceae (includes 3 species in each); Betulaceae, Polygonaceae, Lamiaceae includes 3 species and 1 species found in following families: Ranunculaceae, Solanaceae, Fabaceae, Papaveraceae, Urticaceae, Brassicaceae, Plantaginaceae, Eguisetaceae, Scrophulariaceae, Hypericaceae, Adoxaceae, Tiliaceae, Dryopteridaceae, Elaegnaceae, Paeoniaceae, Polemoniaceae, Grossulariaceae, Salicaceae, Melanthiaceae, Violaceae, Cannabineae (Fig 1.).

Table 1. Medicinal Plants Summary data.

\begin{tabular}{|c|c|c|c|c|c|}
\hline $\mathbf{N}$ & Medicinal plant name & Family & $\begin{array}{l}\text { Life- } \\
\text { form }\end{array}$ & ECG & $\begin{array}{c}\text { Raw material } \\
\text { type }\end{array}$ \\
\hline 1. & Adonis vernalis L. & Ranunculaceae & PHP & meadow & herb \\
\hline 2. & Hyoscyamus niger L. & Solanaceae & BHP & ruderal & leaves \\
\hline 3. & Betula pendula Roth. & Betulaceae & $\mathrm{T}$ & forest & $\begin{array}{c}\text { gemma, } \\
\text { leaves }\end{array}$ \\
\hline 4. & $\begin{array}{c}\text { Betula pubesccens } \\
\text { Ehrh. }\end{array}$ & Betulaceae & $\mathrm{T}$ & forest & $\begin{array}{c}\text { gemma, } \\
\text { leaves }\end{array}$ \\
\hline 5. & $\begin{array}{c}\text { Crataegus sanguinaea } \\
\text { Pall. }\end{array}$ & Rosaceae & $\mathrm{S}$ & forest & flowers, fruits \\
\hline 6. & Centaurea cyanus L. & Asteraceae & OT & ruderal & flower \\
\hline 7. & $\begin{array}{l}\text { Bupleurum multinerve } \\
\text { DC. }\end{array}$ & Apiaceae & MT & meadow & herb \\
\hline 8 & Polygonum aviculare L. & Polygonaceae & AHP & ruderal & herb \\
\hline 9. & $\begin{array}{c}\text { Polygonum hydropiper } \\
\text { L. }\end{array}$ & Polygonaceae & AHP & $\begin{array}{l}\text { semi- } \\
\text { aquatic }\end{array}$ & herb \\
\hline 10. & $\begin{array}{c}\text { Peucedanum morisonii } \\
\text { Bess.ex Spreng. }\end{array}$ & Apiaceae & PHP & steppe & roots \\
\hline 11. & $\begin{array}{l}\text { Melilotus officinalis (L.) } \\
\text { Pall. }\end{array}$ & Fabaceae & BHP & ruderal & herb \\
\hline 12. & Origanum vulgare L. & Lamiaceae & PHP & meadow & herb \\
\hline 13. & $\begin{array}{l}\text { Hypericum perforatum } \\
\text { L. }\end{array}$ & Hypericaceae & PHP & meadow & herb \\
\hline 14. & Fragaria vesca L. & Rosaceae & PHP & forest & leaves, fruits \\
\hline 15. & Viburnum opulus L. & Adoxaceae & $\mathrm{S}$ & forest & fruits, cortex \\
\hline 16. & Pinus sibirica Ledep. & Pinaceae & $\mathrm{T}$ & forest & strobile \\
\hline 17. & Verbascum thapsus L. & Scrophulariaceae & BHP & ruderal & flowers \\
\hline 18. & Urtica dioica L. & Urticaceae & PHP & ruderal & leaves \\
\hline 29. & $\begin{array}{c}\text { Sanguisorba officinalis } \\
\text { L. }\end{array}$ & Rosaceae & PHP & meadow & $\begin{array}{l}\text { rhizomes and } \\
\text { roots }\end{array}$ \\
\hline 20. & $\begin{array}{l}\text { Filipendula ulmaria (L.) } \\
\text { Maxim. }\end{array}$ & Rosaceae & PHP & meadow & flowers \\
\hline 21. & Potentilla argentea L. & Rosaceae & PHP & forest & herb \\
\hline 22. & Tilia cordata Mill. & Tiliaceae & $\mathrm{T}$ & forest & flowers \\
\hline 23. & Arctium lappa L. & Asteraceae & PHP & ruderal & Kroots \\
\hline 24. & Rubus idaeus L. & Rosaceae & $\mathrm{S}$ & forest & fruits \\
\hline 25. & Tussilago farfara L. & Asteraceae & PHP & ruderal & $\begin{array}{l}\text { leaves, } \\
\text { flowers }\end{array}$ \\
\hline 26. & $\begin{array}{l}\text { Dryopteris filix- mas } \\
\text { (L.) Schott. }\end{array}$ & Dryopteridaceae & PHP & forest & rhizome \\
\hline
\end{tabular}




\begin{tabular}{|c|c|c|c|c|c|}
\hline 27. & $\begin{array}{c}\text { Hippophae rhamnoides } \\
\text { L. }\end{array}$ & Elaeagnaceae & $\mathrm{S}$ & $\begin{array}{l}\text { semi- } \\
\text { aquatic }\end{array}$ & плоды \\
\hline 28. & $\begin{array}{l}\text { Taraxacum officinale } \\
\text { Web. }\end{array}$ & Asteraceae & PHP & ruderal & roots \\
\hline 29. & $\begin{array}{l}\text { Capsélla bursa pastóris } \\
\text { (L.) Medik. }\end{array}$ & Brassicaceae & AHP & ruderal & herb \\
\hline 30. & Tanacetum vulgare L. & Asteraceae & PHP & meadow & flowers \\
\hline 31. & Paeonia anomala L. & Paeoniaceae & PHP & forest & $\begin{array}{c}\text { herb, } \\
\text { rhizomes and } \\
\text { roots }\end{array}$ \\
\hline 32. & Abies sibirica Ledeb. & Pinaceae & $\mathrm{T}$ & forest & $\begin{array}{c}\text { needle, } \\
\text { gemma, } \\
\text { branch, cortex }\end{array}$ \\
\hline 33. & Plantago major L. & Plantaginaceae & PHP & meadow & leaves \\
\hline 34. & Artemisia absinthium L. & Asteraceae & PHP & ruderal & herb, leaves \\
\hline 35. & $\begin{array}{c}\text { Leonurus } \\
\text { guinguelobatus Gilib. }\end{array}$ & Lamiaceae & PHP & ruderal & herb \\
\hline 36. & Sorbus sibirica Hedl. & Rosaceae & $\mathrm{T}$ & forest & fruits \\
\hline 37. & $\begin{array}{l}\text { Polemónium caeruléum } \\
\text { L }\end{array}$ & Polemoniaceae & PHP & forest & $\begin{array}{l}\text { rhizomes and } \\
\text { roots }\end{array}$ \\
\hline 38. & Pinus sylbestris L. & Pinaceae & $\mathrm{T}$ & forest & $\begin{array}{c}\text { gemma, } \\
\text { needle }\end{array}$ \\
\hline 39. & Ribes nigrum L. & Grossulariaceae & $\mathrm{K}$ & forest & fruits \\
\hline 40. & Carum carvi L. & Apiaceae & BHP & meadow & seeds \\
\hline 41. & Populus nigra L. & Salicaceae & $\mathrm{T}$ & $\begin{array}{l}\text { semi- } \\
\text { aquatic }\end{array}$ & gemma \\
\hline 42. & Achillea millefolium L. & Asteraceae & PHP & meadow & herb, flowers \\
\hline 43. & Chelidonium majus L. & Papaveraceae & PHP & ruderal & herb \\
\hline 44. & $\begin{array}{l}\text { Veratrumm lobelianum } \\
\text { Bernh. }\end{array}$ & Melanthiaceae & PHP & forest & $\begin{array}{l}\text { rhizomes and } \\
\text { roots }\end{array}$ \\
\hline 45. & Bidens tripartita L. & Asteraceae & AHP & $\begin{array}{l}\text { semi- } \\
\text { aquatic }\end{array}$ & herb \\
\hline 46. & Padus avium Mill. & Rosaceae & $\mathrm{T}$ & forest & fruits \\
\hline 47. & Viola arvensis Murr. & Violaceae & AHP & ruderal & herb \\
\hline 48. & Eguisetum arvense L. & Equisetaceae & PHP & meadow & herb \\
\hline 49. & Humulus lupulus L. & Cannabineae & PHP & forest & seedlings \\
\hline 50. & Rosa majalis Herm. & Rosaceae & $\mathrm{S}$ & meadow & fruits \\
\hline 51. & Rosa accicularis Lindl. & Rosaceae & $\mathrm{S}$ & forest & fruits \\
\hline
\end{tabular}

Notes: LF - life forms, T - trees, S - shrubs, PHP - perennial herbaceous plants, BHP - biennial herbaceous plants, AHP - annual herbaceous plants, ECG - ecological cenotic groups. 


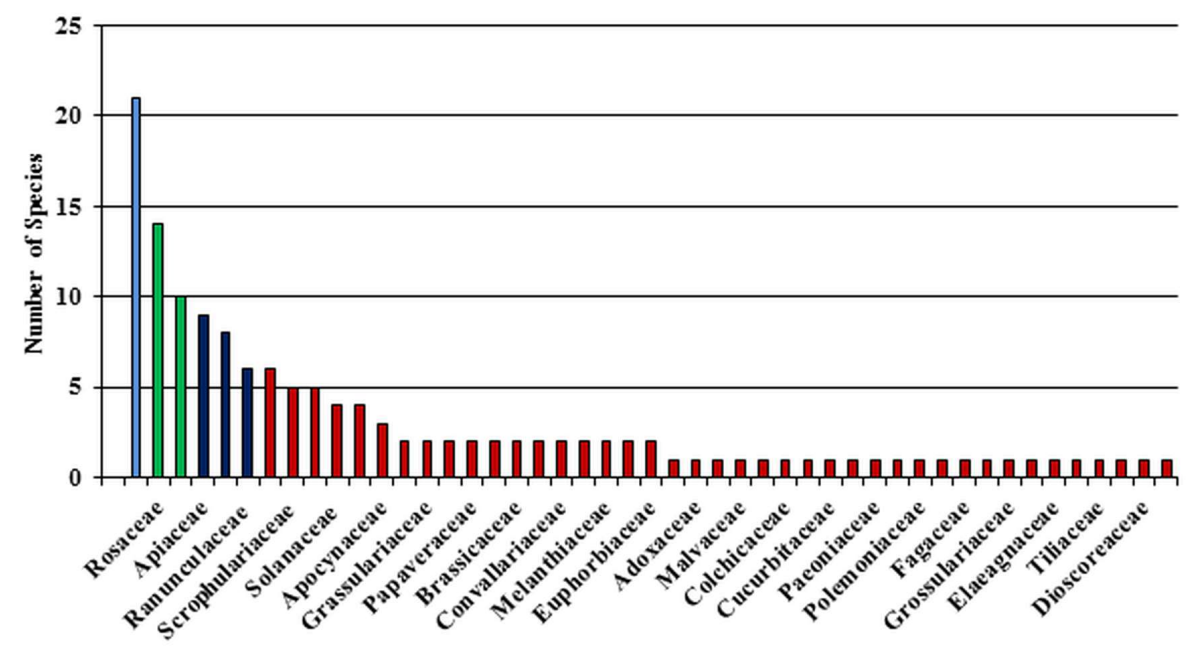

Fig.1. The medicinal plants species distribution by families.

The dump medicinal flora ecological-cenotic groups analysis showed that forest $(20$ species), ruderal (14 species) and meadow (12 species) vegetation prevail in the phytocenosis structure - 39.22; 27.45 and $23.53 \%$, which overall makes up $90.20 \%$ of the identified medicinal plants total number. The share of semi-aquatic vegetation (4 species) and steppe vegetation ( 1 species) accounts for $7.84 \%$ and $1.96 \%$, respectively (Table 1, Fig. 2).

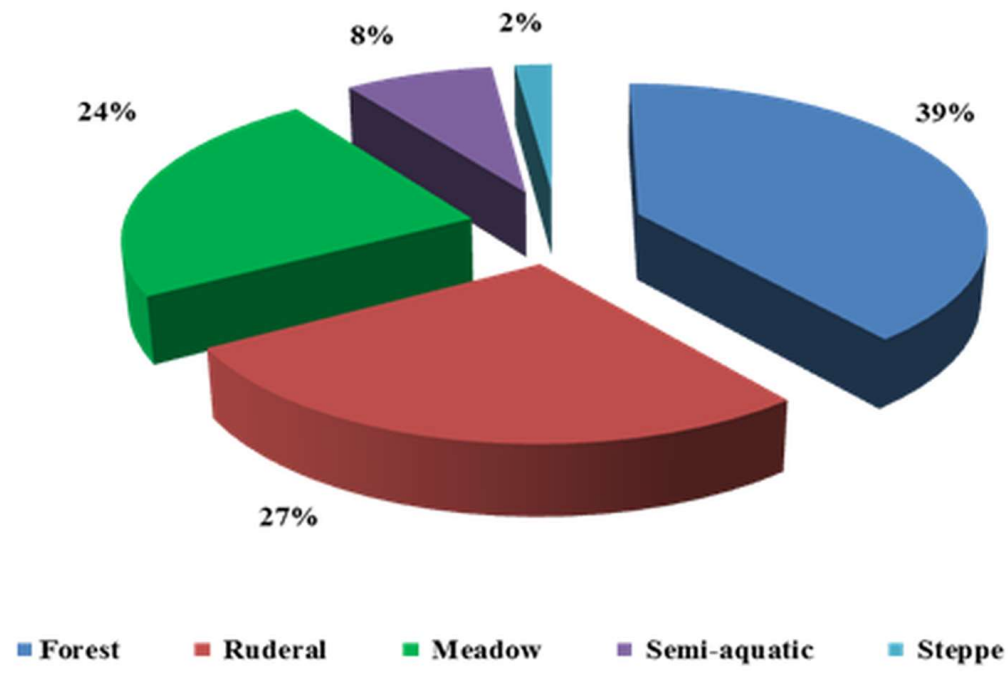

Fig.2. Medicinal plants distribution by ecological-cenotic groups.

The medicinal flora analysis showed that herb plants prevail, of which $49.02 \%$ (25 species) are perennial herbaceous plants (PHP), 9.8\% (5 species each) biennial and annual plants (BHP,AHP), 13 , 73\% (7 species) - bushes (S) and 13.65\% (9 species) - trees (T) (Fig. 3). 


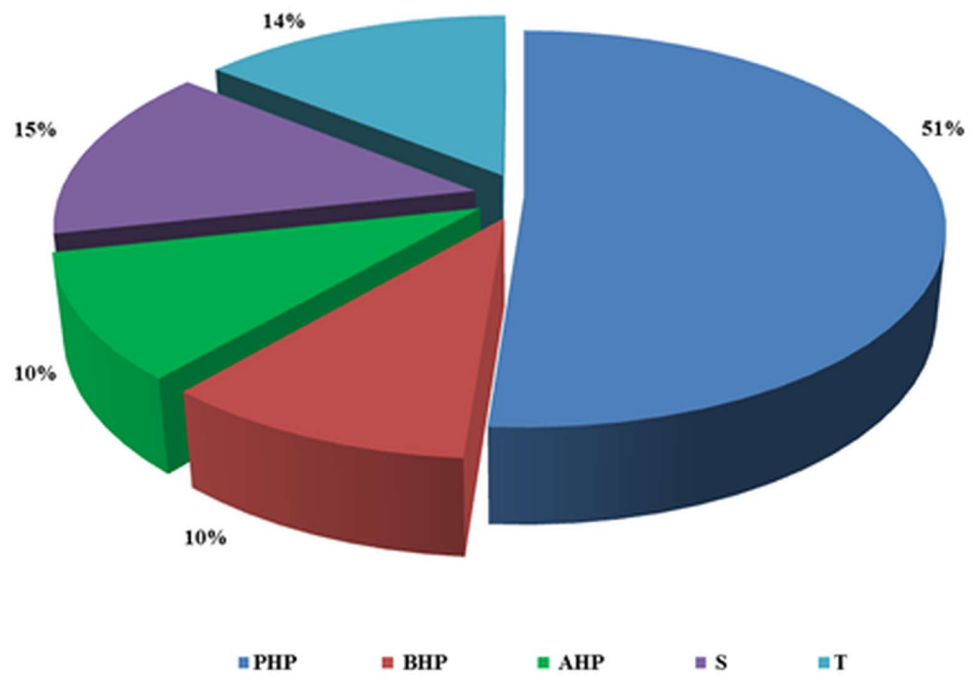

Fig. 3. The medicinal plants life forms composition.

23 species which often form thickets are interesting for resource studies and for raw material procurement (Table 2).

It is possible to harvest various types raw materials of medicinal plants identified on waste dumps. For example, in 11 types of herbaceous perennials the aboveground part (herb) is used as a raw material. In a significant part, underground organs are harvested ( 8 species), in 4 species - flowers and inflorescences, in 5 - leaves, and in 1 species - fruits and seedlings. In most cases in annual plants harvest herb - 5 species; in one species, flowers. Biennial herbaceous plants harvest seeds, fruits, flowers, leaves and grass.

Table 2. The forming thickets medicinal plant group identified on the dumps.

\begin{tabular}{|c|c|}
\hline Medicinal plant Latin names & Life forms \\
\hline Achillea millefolium L. & \\
Viola arvensis Murr. & \\
Polygonum aviculare L. & \\
Melilotus officinalis (L.) Pall. & \\
Fragaria vesca L. & Herbaceous plants \\
Verbascum thapsus L. & \\
Urtica dioica L. & \\
Filipendula ulmaria (L.) Maxim. & \\
Tussilago farfara L. & \\
Taraxacum officinale Web. & \\
Tanacetum vulgare L. & \\
Plantago major L. & \\
Artemisia absinthium L. & \\
\hline Crataegus sanguínea Pall. & \\
Hippophaë rhamnoides L. & \\
Rosa accicularis Lindl. & \\
Rosa majalis Herm. & \\
Viburnum opulus L. & \\
\hline
\end{tabular}




\begin{tabular}{|c|c|}
\hline Betula pendula Roth. & \\
Betula pubesccens Ehrh. & Trees \\
Padus avium Mill. & \\
Sorbus sibirica Hedl. & \\
Pinus sylbestris L. & \\
\hline
\end{tabular}

13 species of herbaceous plants, 5 species of shrubs and 5 species of trees are form thickets.

In contrast to herbaceous plants, tree forms and shrubs often use fruits, buds, leaves, shoots, bark, flowers, and inflorescences as raw materials (Table 1).

It also should be noted that medicinal plants growing on the studied dump used in homeopathy and being raw materials for dietary supplements. These are more than 60 species of plants (Geranium pratense L., Convolvulus arvensis L., Erysimum cheiranthoides L., Salix alba L., Trifolium pratense L., Potentilla anserina L., Pulmonaria obscura Dumort., Etc.) [16].

\section{Conclusion}

The Kedrovsky mine waste dump "Yuzhny" phytocenosis, there are 51 medicinal plants species belonging to 46 genus and 27 families permitted for use in official medicine in the territory of the Russian Federation.

The ecological-cenotic groups analysis of dump medicinal flora showed that forest, ruderal and meadow vegetation prevails in the structure of phytocenosis, which is 39.22 ; 27.45 and $23.53 \%$, respectively. The share of semi-aquatic and steppe vegetation accounts for $7.84 \%$ and $1.96 \%$, respectively.

The life forms composition is dominated by perennial herbaceous plants ( 25 species); shrubs and trees of 7 and 9 species, respectively.

Research has established a medicinal plants group with resource potential and the raw materials procurement interest. It includes 13 species of herbaceous plants, 5 species of shrubs and 5 species of trees.

The work was carried out according to the state task - No 0352-2019-0015

\section{References}

1. L. P. Barannik, Forest remediation bioecological principles (SibNauka, Novosibirsk, 1988)

2. Yu. A. Manakov, T. O. Strelnikova, A. N. Kupriyanov, The Formation of Plant Cover in Man-Made andscapes of the Kuznetsk Basin (SO RAN Pub., Novosibirsk, 2011)

3. Y. Manakov, Revegetation in technogenic landscapes of Kuzbas (KemSU, Kemerovo, 2012)

4. I. N. Egorova, The possibility of using the reclaimed lands of the coal mine "Kedrovskii" for the harvesting of medicinal plant raw material. The Development of a Set of Technologies for Reclaiming Industrial Lands (KemSU, Kemerovo, 2011)

5. D. A. Muraveva, I. A. Samilina, G. P. Yakovlev, Pharmacognosy (Medicine, Moscow, 2002)

6. I. N. Egorova, O. A. Neverova, L. S. Dyshlyuk, J. Mod. App. Sc., 4, 270-275 (2015) 
7. N. Egorova, I. Egorova, E. Maltseva, A. Sukhikh, E3S Web Conf., 26, 02023 (2018)

8. I. N. Egorova, O. A. Neverova, OGU Bul., 10:185, 385-387 (2015)

9. O. N. Egorova, O. A. Neverova, I. N. Egorova, J. Mod. Prob. Sc. Ed., 6, 1373 (2014)

10. O. A. Neverova, I. N. Egorova, J. Food Processing: Techniques and Technology, 3:38, 139-146 (2015)

11. O. N. Egorova, I. N. Egorova, T. I. Grigorieva, Problems of nature protection organization of landscapes, 1, 71-75 (2013)

12. I.N. Egorova, O. A. Neverova. World Applied Sciences Journal, 27, 497-500 (2013)

13. I. N. Beideman, Methods of studying the plants and plant communities phenology (SibNauka, Novosibirsk,1974)

14. S. K. Cherepanov, Vascular plants of Russia and adjacent states (within the former USSR) (Piter, St. Petersburg, 1995)

15. The Kedrovsky mine mining and transport part project (Kedrovsky Surface Mine Pub., Keverovo, 1996)

16. Dietary Supplements Federal Register (MSDA, Moscow, 2005) 